\title{
Environmental Influences on Trade Activities in the 19th Century East Coast Sumatra
}

\author{
Saparudin Barus*, Singgih Tri Sulistiyono, Yety Rochwulaningsih, Endang Susilowati \\ Departement of History, Faculty of Humanities, Diponegoro University, Semarang, Indonesia
}

\begin{abstract}
This study examines the factors supported on the relationship between environmental or regional conditions affected the development of trading activities. To examine this problem, historical methods are used which include four stages, namely heuristics, criticism, interpretation, and historiography. Meanwhile, this study used a geostrategic and geopolitical approach. The result shows that the dynamic trade activity in the East Sumatra Region in the 19th century was inseparable from the strategic regional position which faces directly to the Malacca Strait which is the center of the largest maritime economic activity in the Southeast Asian region as well as connecting the 'world' from the east and west. Therefore, geopolitically, there were many forces fighting over the region including the Sumatra coastal area which importantly become the hinterland area for the international trading commodity, especially to Asia and Europe. It was evidenced by a large number of foreign investors developing tea plantations in the East Sumatra region which then stimulated the growth of ports in the coastal regions of East Sumatra with very dynamic trading activities.
\end{abstract}

Keywords: Environmental Influences; Trading Activities; Eastern Coast of Sumatra.

\section{Introduction}

East Coast of Sumatera is historically known as an area or territory during the colonial period called Oostkust (East Coast). Colonization in this area was initiated by European and American capitalist companies in plantation such as tobacco, rubber, and palm oil. According to Perret [1], East Coast of Sumatera have been a great exploration area for capitalism in this country since colonial era. East Coast of Sumatera is geographically strategic and very open to external contact and interaction. The location that directly faces Malacca Strait allows it to be the route of international trade. Therefore, several routes around the East Coast of Sumatera are bustling ports. Acceptance and openness of the people engaged in the trade activities has made their characteristics to be more open and easily adapt to the influence brought by the foreign merchants in terms of socio-cultural aspect. As stated by Ambary [2] that openness of trade ports affected the characteristics of the maritime society to be more

\footnotetext{
* Corresponding author: ruswitakusumahadi@gmail.com
} 
open, both in its adaptation to new things and openness to accept new cultural aspects and their orientation to economic life from trading.

A number of trade ports and maritime activities along the East Coast of Sumatra, starting from Nanggroe Aceh Darussalam to Lampung Province were experiencing growth and setback phase, and so they were replaced by other trade ports that were more profitable and holding security guarantees from the rulers of the trade port areas. Several places on the East Coast of Sumatera included in North Sumatra Province, have left traces of maritime and trade activities through archaeological remains, including the site of China Town. Many studies and research on these sites were conducted, such as by Milner [4], Ambary [5], and Manguin [6].

The bustling trade activities in the East Coast of Sumatera is inseparable from the emergence of trade ports in East Sumatra, including in the Muara Belawan area which are the China Town Site and Rentang City Site. At these two sites, many discoveries with similarities were found, including: ceramics, pottery, stone, metal, currency, grinding and milling stone, resin, brick, and food waste [7]. The emergence of this trading activity is inseparable from the interests of kingdoms, both from local, neighboring kingdoms and the international community for the commodities traded by the locals. The commodities for trade were produced by the local people. At that time, Anderson wrote in his notes about the travel to Deli regarding an inventory of population, agriculture and political organization in East Sumatera. From Anderson's journey, it is known that East Sumatera people have developed an agricultural system producing export trade commodities. Regarding the important production, according to Anderson [4] that there were main commodities for export from East Sumatra, such as gold, camphor, ivory, wax, pepper (black and white), benjamin, cinnamon, gambier, rattan, sulfur, tobacco, coal, agarwood, dye-woods, ebony wood, various timber for boats, rope for cables, fish eggs, shark fins, sugar, mats, various nuts, rice, dragon's blood, silk and horses. Moreover, there are many other commodities for the needs of the community.

In addition, Anderson [4] also reports that forest and plantation commodity were exported by the people of East Sumatra in 1823 to Penang which was occupied by the British. From the export activities, the currency of the British colonial government entered East Sumatera, including the Straits Settlements coins.

\section{Method}

The method used in this research was literature study. The data source were documents taken from books and archives. The document collection process was conducted by collecting the data from articles, books, photos, images, and data from various reliable sources. The documents were divided into primary and secondary documents. The first was document obtained directly from the first party, while the latter was obtained from the second party. This paper used the second one. The selection of this type of method is based on the fact that field data collection is not required in this writing. It is because that literature study through the analysis of documents, archives and photos has answered the research problems or the phenomena under study. (Zed, 2004). 


\section{Result and Discussion}

East Coast of Sumatera is geographically strategic and very open to external contact and interaction. Located directly facing the Malacca Strait which is the route of international trade, it made several places around the east coast of Sumatera once became a lively trade port at that time. The openness of trade ports affected the characteristics of the maritime society to be more open, both in its adaptation to new things and openness to accept new cultural aspects and their orientation to economic life from trading [2].

Trade is an activity carried out by humans in order to meet their daily needs. In its activities, sales and purchase transaction of goods between the seller and the buyer take place. It happens to meet the supply and demand for the desired item. However, it is not just a mere sales and purchase transaction between the seller and buyer. Herlborner in Nastiti [8] emphasizes that trading is a specific activity because it involves a series of production and distribution activities. Free trade is an economic concept referring to the Harmonized Commodity Description and Coding System (HS) with a number of provisions from the World Customs Organization based in Brussels, Belgium. It is a form of sales of goods between countries without export-import taxes or other barriers. Free trade can also be defined as the absence of artificial barriers (barriers from the government) in trade between individuals and companies of different countries [9].

One of the areas in the East Coast of Sumatera is Deli. Deli is an area (region) that during that time was called as a country in the east coast of Sumatera which was fought over by neighboring countries such as Siak, Johor and Aceh. Today, Deli is under the administrative territory of North Sumatra Province located at $4^{\circ} 39$ 'North Latitude, and $98^{\circ} 25^{\prime}$ to $98^{\circ} 47^{\prime}$ East Longitude, which covers the area between Labuhan Dalam River in the north of Langkat border and Pematang Oni River in the south of Serdang border [10]. The development of this area into competitive area in trading is because its fertile land and rich natural resources that cannot be found in other regions. One of the leading areas in East Sumatera is Deli. Deli is an area (region) that during that time was called as a country in the east coast of Sumatera which was fought over since the 17th to 19th century. During the course, Deli area was not only fought over by the Kingdom of Aceh and the Kingdom of Siak, but it has also attracted the ruler of neighboring kingdom of Johor to expand his territory. Since then, these kingdoms had in turn colonized Deli area.

In the 19th century, more and more parties were interested to the East Coast of Sumatera, especially Deli. Not only local kingdoms, and neighboring kingdoms, but also the international community were interested in this area. The British, for instance, managed to enter and occupied this area in the 19th century (1800s) through the neighboring area of Penang. Penang is a port and international trade area, especially for the market and export and import of goods, particularly pepper from (and to) Penang for merchants from neighboring countries including from the east coast of Sumatera. Due to a great curiosity to the small ports in the remote areas as the meeting points and trading points of agricultural commodities and agricultural production centers for inland farmers, the British sent John Anderson to carry out an inventory of the situation of East Sumatera people. The inventory conducted by John Anderson was about population, agriculture, and political organization in East Sumatera. From Anderson's journey, it is known that Deli people have developed an agricultural system that produced export trade commodities.

Deli is indeed well-known for its fertile land and rich natural resources. The fertility and richness of the land in Deli is depicted by Anderson in detail from the results of his inventory and visit to East Sumatera. In his narration, he reports that the land is very abundant, like a black mold. However, getting to Asahan, the soil is not quite good. There is mountanious area which have red and sandy soils, mixed with granite grains and seeds of fluffed fruit. 
Regarding why the Deli area is so fertile and has high economic value, Perret [1] states that the fertile soil was due to volcanic activity resulting in the formation of sediment containing andesite and dacite in the north of the lake to Medan. The volcanic activity affects the structure of the soil, especially for the tobacco. Meanwhile, Pelzer [11] revealed that this area was very potential for tobacco cultivation, especially the area between Wampu River and Ular River. According to Pelzer, the key to understanding the amazing growth of onderneming areas in East Sumatera is geological condition and those that are closely related to the shape of the land and its soil.

Table 1. Agricultural Export Commodity from Plantation and Community Forest

\begin{tabular}{|c|c|c|c|}
\hline No & Region & Commodities & Description \\
\hline \multirow[t]{6}{*}{1} & \multirow[t]{6}{*}{ Langkat } & Pepper & $\begin{array}{l}\text { Good quality. exported to America / } \\
\text { Europe. } 20,000 \text { piculs / year. }\end{array}$ \\
\hline & & & \multirow{5}{*}{ - Exported to China } \\
\hline & & Rattan & \\
\hline & & Gambir & \\
\hline & & Paddy & \\
\hline & & Abar wood & \\
\hline 2 & $\begin{array}{l}\text { Soonghal } \\
\text { (Sunggal) }\end{array}$ & & $\begin{array}{l}\text { No less than } 20,000 \text { Batak } \\
\text { cultivation }\end{array}$ \\
\hline 3 & $\begin{array}{l}\text { Bulu Cina } \\
\text { (daerah Deli) }\end{array}$ & $\begin{array}{l}\text { Pepper } \\
\text { Gambir }\end{array}$ & $\begin{array}{l}15.000 \mathrm{picul} / \text { year export to Pinang and } \\
\text { Malacca }\end{array}$ \\
\hline \multirow[t]{8}{*}{4} & \multirow[t]{8}{*}{ Delli (Deli) } & Pepper & $\begin{array}{l}\text { Meidan (Medan) with population of } 200 \\
\text { peopl and Batak Karo } \pm 5.000 \text { people }\end{array}$ \\
\hline & & Paddy & Yield 26,000 picul in 1822 \\
\hline & & Tobacco & For household consumption \\
\hline & & $\begin{array}{l}\text { Coconut and areca } \\
\text { nut }\end{array}$ & $\begin{array}{l}\text { Export (planted, cultivated, and harvested } \\
\text { regularly). }\end{array}$ \\
\hline & & Wood & The plantations of coconut very extensive. \\
\hline & & Gambir & Export to Pinang. \\
\hline & & Pepper & Export \\
\hline & & Sago & Below Deli \\
\hline
\end{tabular}

From the rich natural resources and the privileges and fertility of its land, the economic in Deli was growing and developing rapidly. In addition, Deli was once the center of tobacco plantation and producing the best quality tobacco leaves. Deli tobacco is the best cigarette wrap in the world. In only 40 years since Nienhuys opened its first tobacco plantation, 140 plantations companies were established. Furthermore, the East Sumatera region was also a plantation for other important commodities such as rubber and palm oil. At that time, East Sumatra was also known as the land of the dollar.

In the mid-19th century, Deli attracted foreign investors in developing and expanding of plantation in Deli. Deli was considered to have a great economic potential and has promoted as "The Land of Dollar" because of the popularity of its tobacco production. The arrival of plantation entrepreneur during the Deli plantation period (1863) made this area developed rapidly both economically, socially and culturally. It brought impacts on the social changes. The traces of plantation development can be seen from the existence of historic buildings including offices, shops, hospitals, schools, banks, bridges, roads, hotels, houses of worship, official houses, warehouses, sports facilities, water towers, etc. These buildings have a distinctive architectural style, layout, and regional development characteristics in European nuance, or it can be said that it has the traces of prototypes of European cities. 


\section{Conclusion}

East Coast of Sumatera is one of the important areas in international trade activities. It is indicated by the nickname of the Deli as the land of dollar. In addition, the artifact remains of trade traces are shown from the city prototype with European nuances. The emergence of a trading area is inseparable from the natural, environmental and social factors. The topographical characteristics of Deli have produced the best quality tobacco leaves in the world. In addition, the quality of this tobacco can only be produced by Deli land.

\section{Acknowledgment}

This article is funded by Directorate DRPM DIKTI 2020 under the research Doctoral Dissertation Program (255-10/UN7.6.1/PP2020).

\section{References}

[1]. Daniel Perret, Kolonialisme dan Etnisitas. Batak dan Melayu di Sumatra Timur Laut, Jakarta: KPG, (2010)

[2]. H. Muarif Ambary, "Peranan Beberapa Bandar Utama i Sumatera Abad Ke-7-16 M Dalam Jalur Perdagangan Internasional", Proceedings International Symposium For japanese Ceramics of Archaeological Sites in South East-Asia: The Maritime Relationship on 17th Century, Jakarta: Pusat Arkeologi dan The Japan Foundation, pp. 12-21 (2000)

[3]. A.C. Milner, “A Note on Aru dan Kota Cina," Indonesia 26, pp. 1 1-42 (1978)

[4]. Jhon Anderson, Mission to the East Coast of Sumatra Under the Direction of the Government of Prince of Wales Island. William Blackwood, Edinburgh and London: Blackwood (1826)

[5]. H. Muarif Ambary, "Further Notes on Classification of Ceramics from the Excavation of Kota Cina", Studies on Ceramics, pp. 63-72 (1984)

[6]. P. Y. Manguin, "The Trading Ships of Insular South-East Asia”, Pertemuan Ilmiah Arkeologi V. Jakarta: IAAI, pp. 200-219.

[7]. Naniek Harkantiningsih and S. Wibisono, "Kota Rentang, Sumatera Utara: Jalur Perdagangan Pantai Timur Sumatra." AMERTA, Jurnal Penelitian dan Pengembangan Arkeologi, Vol. 30, No. 1, (2012)

[8]. Titi Surti Nastiti, Pasar di Jawa pada Masa Mataram Kuna Abad VIII - IX Masehi. Jakarta: PT. Dunia Pustaka Jaya, (2013)

[9]. http://ekosuwono.wordpress.com/

[10]. Edi Ikhsan, “Antan Patah Lesungpun Hilang: Pergeseran Hak Tanah Komunal dan Pluralisme Hukum dalam Perspektif Sosio-Legal (Studi pada Etnis Melayu Deli Sumatera Utara)," Disertasi: Universitas Sumatera Utara, (2013)

[11].Karl Pelzer, Toean Keboen dan Petani, Jakarta: Sinar Harapan, (1985) 